\title{
Quality research of aqueous extracts of green and red tea
}

\section{Kristina Ramanauskiené ${ }^{1}$}

Aidas Grigonis ${ }^{2}$,

Valdimaras Janulis ${ }^{3}$,

Raimondas Raudonis ${ }^{3}$,

Lina Babickaitè2,

Asta Marija Inkèniené ${ }^{1}$

${ }^{1}$ Department of Clinical Pharmacy,

Faculty of Pharmacy,

Lithuanian University of Health Sciences,

Sukilèliai Ave. 13,

50162 Kaunas, Lithuania

${ }^{2}$ Dr. L. Kriaučeliūnas Small Animal Clinic,

Veterinary Faculty,

Veterinary Academy,

Lithuanian University of Health Science,

Tilžès St. 18, 47181 Kaunas, Lithuania

${ }^{3}$ Department of Pharmacognosy,

Faculty of Pharmacy,

Lithuanian University of Health Sciences,

Sukilèiai Ave. 13,

50162 Kaunas, Lithuania
Green and red tea due to the strong antioxidant, anti-inflammatory, anti-microbial, anti-tumor features are an intensive object of research. This article explores the chemical composition and biological activity of green and red tea of different fermentation. The preparation of aqueous extracts was implemented in household conditions, and the extraction time of release of active compounds from raw material was evaluated. The antibacterial activity was evaluated by the method in vitro. The research has shown that green tea is rich in catechins and caffeine. Red tea provides rutin and gallic acid. Green tea extracts inhibited the growth of $S$. aureus ir B. cereus. On the basis of the research results on the antioxidant activity, teas can be arranged in the following sequence: green $>$ white $>$ Oolong $>$ red.

Keywords: tea, quality research, catechins, antibacterial activity

\section{INTRODUCTION}

Tea is the second most popular beverage in the world after water [1]. Green tea is prepared from dried Camellia sinensis leaves and buds by adding hot water for a few minutes [2]. The raw material of green tea is produced without the fermentation stage. During the hot-air drying process enzymes are inactivated, less volatile substances remain in raw material and leaves preserve their green colour.

\footnotetext{
* Corresponding author. Email: asta.inkeniene@lsmuni.lt
}

Oolong tea is a partially fermented tea, occupying an intermediate position between the unfermented green tea and the fully fermented black tea [3]. White tea is comprised of new, young and delicate tea leaves and buds, which are naturally dried and then dried at low temperature [П]. The plant raw material of red tea is collected from rooibos (Aspalathus linearis) bush leaves and stems [5]. Green tea has recently become the subject of an intensive research due to its abundant and diverse biological effect if compared to the other teas mentioned above. The results of different researches show that one of the main flavonoids' 
groups, found in the dried leaflets of Aspalathus linearis as well as in the buds and leaflets of Camellia sinensis L., are flavonols: quercetin, myricetin and kaempferol [6, 帊. Comparing green tea with the red one in respect of catechins, flavonols are synthesized in order to form catechins in the plant of Camellia sinensis L., but this is not the synthesis mechanism of the plant Aspalathus linearis [8]. Flavonols (flavan-3-ol) are one of the main biologically active compounds of Camellia sinensis L. plant causing its therapeutic properties. Aspalathus linearis is unique in its monomeric flavonoid composition, containing two unique compounds, namely aspalathin and aspalalinin [9]. Aqueous leaf extracts are known as natural sources of antioxidants capable of reducing the violations of tissues caused by free radicals in the body [ $6,10-12]$. Joubert and others examined the aqueous extracts of green and red tea and found that the quercetin has the strongest antioxidant activity. Weaker antioxidant activity was determined for aspartic acid, orientin, luteolin and isoquercetin [12]. Research data about the antimicrobial activity of green tea leaves extract against skin pathogens in vitro can also be found [13]. The research data state that green tea is characterized by the highest antimicrobial activity, and a lower activity is common for red tea [10].

In order to reach quality in tea preparation there should be the influence of technological parameters on the quality of aqueous extracts evaluated. Tea can be prepared in many different ways in different countries around the world: it can be steeped with different temperatures of water, for example, it can be served with milk, lemon juice, honey or sugar additives [8]. Tea preparation technology depends not only on traditions, but also on medical goals if it is used in the form of decoction or infusion, which are prepared in the way of maceration [5]. That is why it is important to assess the possible influence of technological parameters on the quality of tea extracts. The goal of this study is to investigate the quality of the aqueous extracts of raw material plant of green tea (Camellia sinensis L.) and red tea (Aspalathus linearis (Burm. F.).

\section{Experimental}

Raw material. The objects of investigation is the raw material of green and red tea, which is homogeneous and without additional additives (taste, aroma-enhancing substances). For this research the green tea China Gunpowder (N1) and Japan Bancha (N2), the white tea Pai Mu Tan (N3), the partially fermented green tea Jade Oolong (N4) and the red tea Rooibos Original (N5) were used.

Reagents and standards. All the reagents and standards were of analytical grade. HPLC-grade acetonitrile and trifluoroacetic acid (TFA) were obtained from SigmaAldrich GmbH (Buchs, Switzerland). Epigallocatechin, epigallocatechin gallate, epicatechin gallate, gallic acid, caffeine were obtained from Sigma-Aldrich GmbH (Steinheim, Germany). Catechin, epicatechin and rutin were obtained from Extrasynthese (Genay, France). Deionized water was acquired from the Milli-Q purification system (Bedford, USA).

Production of aqueous extracts of tea. Five grams of tea are filled with $250 \mathrm{ml} 90^{\circ} \mathrm{C}$ purificated water. Samples are taken after 5, 10, 15 and 20 min of the filling.

2.2-Diphenyl-1-picrylhydrazyl (DPPH) radical binding method. The DPPH free radical solution, when attaching a proton, changes its colour from purple into yellow, and loses the ability to absorb at $517 \mathrm{~nm}$. The ability of the extract to bind the free radical was determined using the modified DPPH binding method described by BrandWilliams et al. [14]. The solution $(25 \mu \mathrm{l})$ of the plant extract was dissolved in methanol and later was diluted with a $0.1 \mathrm{mM}$ DPPH solution in ethanol up to $2.0 \mathrm{ml}$, and the absorbance was measured at $517 \mathrm{~nm} 5 \mathrm{~min}$ after mixing. The activity of the tested compounds was calculated relative to the measured absorbance of the control measurement. Quantification was done on the basis of the standard calibration curve of catechine.

HPLC analysis. The chromatographic analysis was carried out using the Waters Alliance e2695 Separations Module equipped with a Waters 2998 PDA Detector (Milford, USA). The separation was performed on an ACE Excel 3 SuperC18 analytical column (Aberdeen, Scotland) $(250 \times 4.6 \mathrm{~mm}, 3 \mu \mathrm{m})$ at $25^{\circ} \mathrm{C}$. The mobile phase consisted of $0.1 \%$ TFA in deionized water (A) and acetonitrile (B). The gradient elution was as follows: $0-30 \mathrm{~min}, 15-30 \%$ B; 30-50 min, 30-60\% B; 50-55 min, 60-90\% B; and 55$60 \mathrm{~min}, 90-15 \% \mathrm{~B}$. The flow rate was $0.5 \mathrm{~mL} \mathrm{~min}^{-1}$, and the injection volume was $10 \mu \mathrm{L}$. The detector was set in the $200-400 \mathrm{~nm}$ range. Identification of the compounds was done by comparison of their retention time and UV absorption spectrum with those of the standards.

Study of antibacterial activity. The antibacterial properties of the tea extracts were evaluated in vitro using the agar diffusion method. Müller-Hinton agar was used (Mueller-Hinton agar Oxoid LTD (CM 0337), Bsingstoke, Hampshire, England). In vitro studies were performed with the gram positive and gram negative referent bacteria strains Staphylococcus aureus (ATCC 25923), Enterococcus faecalis (ATCC 29212), Bacillus cereus (ATCC 11778), Escherichia coli (ATCC 25922), Pseudomonas aeruginosa (ATCC 27853), Salmonella enterica (ATCC 13076) and the clinical bacteria strains: Staphylococcus aureus, Enterococcus faecalis, Bacillus cereus, Escherichia coli, Salmonella enterica and Pseudomonas aeruginosa. In accordance with the standard approved by the Clinical and Laboratory Standards Institute (CLSI) there was the fluid Mueller-Hinton agar prepared and it was poured in $10 \mathrm{~cm}$ diameter Petri dishes $35 \mathrm{ml}$ each and left in the horizontal position to thicken. There were bacterial strains spread out on the surface of the thickened medium and there were 6 wells (of $7 \mathrm{~mm}$ diameter) made in every Petri dish, which were filled with $0.1 \mathrm{ml}$ of tea extract and water (control test). The plates were incubated for $24 \mathrm{~h}$ at $36^{\circ} \mathrm{C}$. The antibacterial 
activity of extracts in vitro was evaluated after $24 \mathrm{~h}$ of cultivation, calculating the diameter of the transparent areas in millimeters, occurring around the wells. If the transparent area around any well did not appear, it has been concluded that the substance investigated has not got the bactericidal effect on the strain bacteria.

Statistical analysis. The statistical analysis of the data was made by the Microsoft Excel or SPSS programs. Statistical significant differences between the groups were defined when $p<0.05$.

\section{RESULTS AND DISCUSSION}

During the experimental study investigating the impact of tea preparation conditions recommended by tea manufacturers on the quality, it was found that a greater quantity of active compounds was extracted from green tea, compared with red tea. The research had shown (Fig. 11) that catechins and caffeine were dominating compounds in extracts N1-N4. Epigallocatechin and epigallocatechin gallate were the most dominant among all catechins, and there were smaller quantities of catechins, epicatechins and epicatechin gallates found in green tea extracts. The greatest amount of all catechins was obtained from green tea called Bancha (N2). Besides, the higher level of caffeine was found in unfermented tea extracts (N1-N3), compared with Oolong tea (N4).
A statistically significant difference $(p<0.05)$ of caffeine quantity was determined in all of the investigated green tea extracts. The data in Fig. 1 show that there were lower quantities of rutin and gallic acid in comparison with other compounds in green tea extracts. While red tea N5 had only gallic acid and rutin from all investigated compounds. The experimental results show that the largest amount of rutin was released from the raw material of red tea, and the lowest one was from white tea. In regard to the sort of teas investigated, a statistically significant difference $(p<0.05)$ was seen among the total quantity of active compounds in the extracts. The experimental results confirmed the research data that catechins are the main secondary metabolites in Camellia sinensis L. plant [15] as well as in Aspalathus linearis (Burm. F.) plant they are flavonols [8].

While evaluating the influence of the extraction time on the quality of extracts, it was found that the largest quantity of catechins was released from the raw material after $15 \mathrm{~min}$ from the start of extraction (Fig. 2). The maximum quantity of catechins was extracted out of green tea N2 when the minimum was extracted out of white tea N3.

There was not a statistically significant difference $(p<0.05)$ among the total quantity of all the catechins in all extractions in the 15 to 20 min intervals. The experimental research found that the release of caffeine from the raw

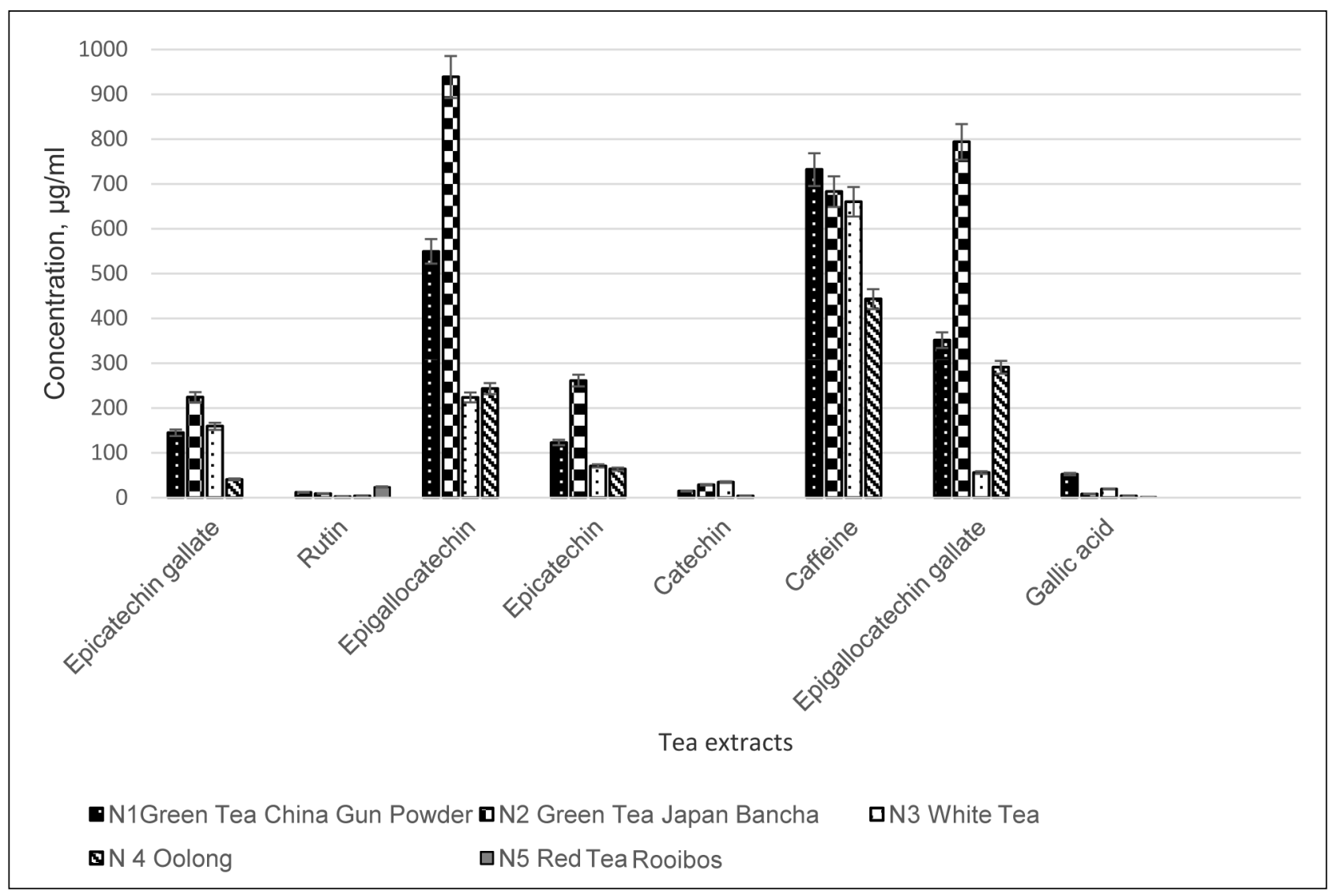

Fig. 1. Quantity of active compounds in tea extracts, $\mu \mathrm{g} / \mathrm{ml}$ (mean $\pm S E M, n=3$ ) 


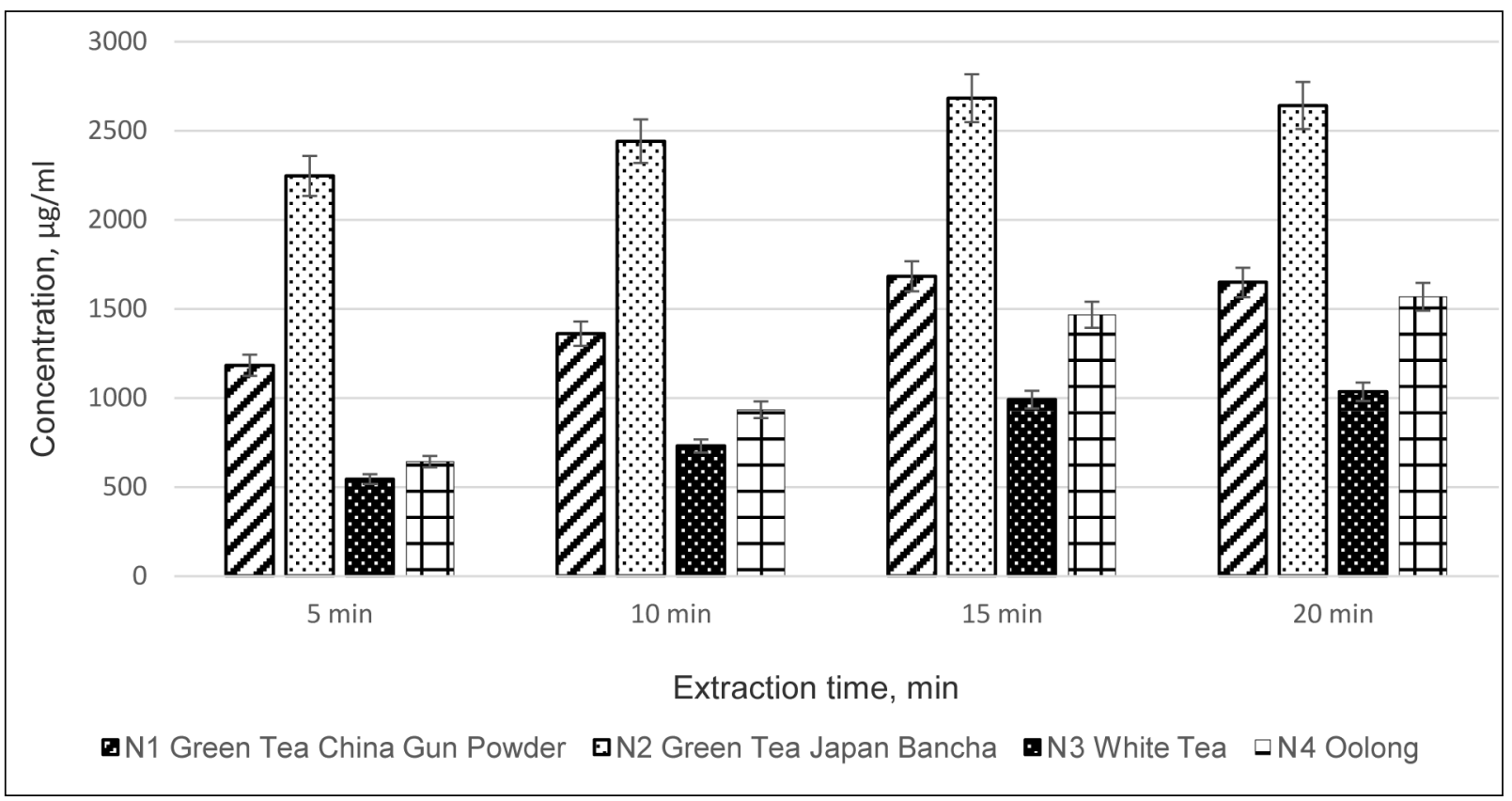

Fig. 2. Research results of the impact of extraction time on the release of catechins from the raw material, $\mu \mathrm{g} / \mathrm{ml}$ (mean $\pm \mathrm{SEM}, n=3$ )

material N1-N3 most intensively proceeded within the period of first $5 \mathrm{~min}$, and then started to slow down (Fig. 3).

The investigation show that there was a direct relevance between the time of extraction and the quantity of the catechins found in green tea extracts. Meanwhile, there was no statistically significant difference between the released quantity of gallic acid (1.759-1.928) and rutin (26.36228.656) after 10 and 20 min of extraction of red tea.

The general antioxidant activity test (Table 1) is significant because it represents the ability of the test objects to bind free radicals in the body, which are the main factors for the mutagenesis of cancerous diseases [16].

On the basis of the test results of the antioxidant activity, teas can be arranged in the following sequence: green $>$ white $>$ Oolong $>$ red. The antioxidant activity of green tea depends on catechins (EGCG, MRC), and gallic acid [16]. Besides, the scientific researches have approved the antioxidant properties of caffeine [17]. The antioxidant activity of red tea may be caused by gallic acid and cumulative flavonols 仴12. The research results confirm that green

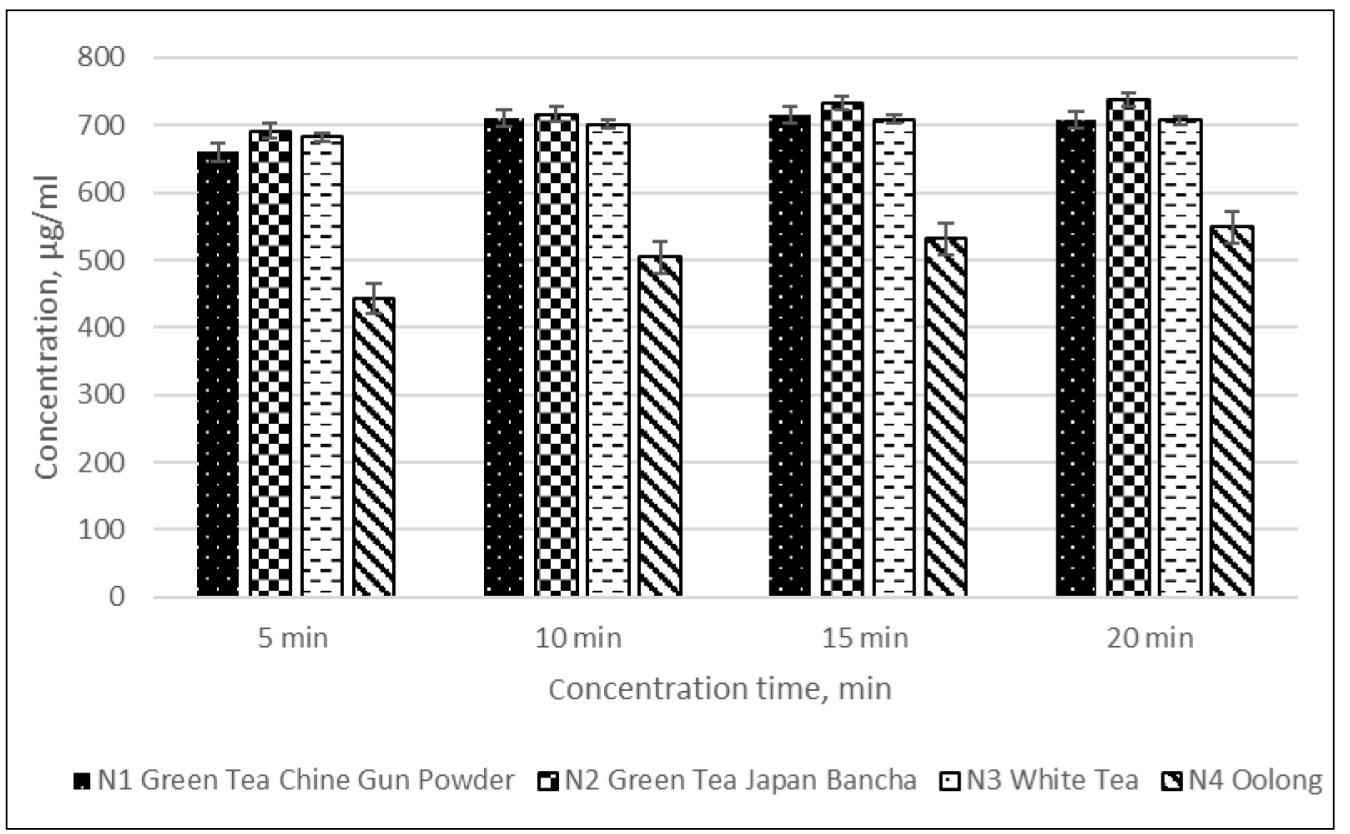

Fig. 3. Quantity of caffeine in tea extracts, $\mu \mathrm{g} / \mathrm{ml}$ (mean $\pm S D, n=3$ ) 
Table 1. Antioxidant activity of tea extracts by DPPH assay, $\%$

\begin{tabular}{c|c|c|c|c|c}
\hline & $\begin{array}{c}\text { N1 green tea } \\
\text { China Gunpowder }\end{array}$ & $\begin{array}{c}\text { N2 green tea } \\
\text { Japan Bancha }\end{array}$ & N3 white tea & N4 Oolong & $\begin{array}{c}\text { N5 red tea } \\
\text { Rooibos Original }\end{array}$ \\
\hline $\mathrm{DPPH}, \%$ & 75.54 & 73.35 & 64.23 & 60.41 & 56.30 \\
\hline
\end{tabular}

tea has the strongest antioxidant properties [10, 12]. It can be concluded that the aqueous extracts of green and red tea are natural sources of the antioxidant substances capable of reducing violations of tissues caused by free radicals in the body [10-12, 14, 16-18].

The antimicrobial activity test determined that green tea extracts inhibited the growth of $S$. aureus clinical strains. There was no significant difference in suppressive effects on the growth of $S$. aureus clinical strains found among all investigated extracts (N1-N4) (Table 2).

The aqueous extract of white tea was the only one which had the inhibited impact on the reference strain of $S$. aureus. N1, N3, and N4 extract samples had the suppressing effects on both: the reference and clinical strains of $B$. cereus. There was no statistically significant difference between the effect of investigated extracts on the reference and clinical $B$. cereus strain found. The red tea extract did not show antimicrobial activity against microorganisms investigated. On the basis of the research literature, unfermented tea (green, white) had the highest antimicrobial activity, the lower antimicrobial activity was seen in partially fermented (red, Oolong) tea and then fermented (black) tea [10]. Our results proved the data in research literature that the Gram (-) bacteria had a higher resistance to polyphenols than the Gram bacteria (+) [19]. Resistance was caused by differences in the cell wall composition of Gram $(+)$ and Gram (-) bacteria: lipopolysaccharides acted as a barrier that lead to less sensitivity to the effects of the catechins in Gram (-) bacteria [10,20]. The scientific literature states that red tea has a weak antimicrobial performance due to the other biologically active substances (rutin, orientin, isoorientin and aspartic acid), but the results of our research have shown that this tea does not have any antimicrobial activity. Oolong tea did not show weaker antimicrobial activity compared to the activity data of green and white tea. We conclude that this could have been caused by the preparation technology of the raw material of Oolong tea. It could be that Oolong tea is only partially fermented tea and the concentration of the active compounds with an antimicrobial effect is reduced due to the fermentation process. On the basis of the research results we may conclude that green and white tea can be applied in composition with other antimicrobials for stabilization of products [21].

\section{CONCLUSIONS}

The experimental studies have found that the extraction time of raw materials affects the release of active compounds. It was established that the largest amount of the active compounds was released from green and white tea within the period of $15 \mathrm{~min}$. It was determined that the proper extraction time of red tea was $5 \mathrm{~min}$. The results of the investigation have shown that the biological effects of tea extracts depend on the sort of tea and the preparation technology of raw material. The strongest antioxidant properties were seen by the green tea Japanese Bancha. Green tea extracts had the antibacterial activity against $S$. aureus and $B$. cereus. The extracts of red tea did not show

Table 2. Evaluation of antimicrobial activity of tea extracts (mean of the diameter of the transparent areas in $\mathrm{mm} \pm \mathrm{SD}, n=3$ ). The extract did not show antimicrobial activity (-)

\begin{tabular}{|c|c|c|c|c|c|c|c|c|c|c|c|c|}
\hline \multirow{5}{*}{ 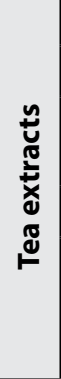 } & \multicolumn{12}{|c|}{ Bacterial strains } \\
\hline & \multicolumn{6}{|c|}{ Gram(+) } & \multicolumn{6}{|c|}{ Gram(-) } \\
\hline & \multicolumn{2}{|c|}{ Staphylococcus aureus } & \multicolumn{2}{|c|}{$\begin{array}{c}\text { Enterococcus } \\
\text { feacalis }\end{array}$} & \multicolumn{2}{|c|}{ Bacillus cereus } & \multicolumn{2}{|c|}{$\begin{array}{c}\text { Pseudomonas } \\
\text { aeruginosa }\end{array}$} & \multicolumn{2}{|c|}{$\begin{array}{l}\text { Esherichia } \\
\text { coli }\end{array}$} & \multicolumn{2}{|c|}{$\begin{array}{c}\text { Salmonella } \\
\text { enterica }\end{array}$} \\
\hline & \multicolumn{2}{|c|}{ ATCC 25923} & \multicolumn{2}{|c|}{ ATCC 29212} & \multicolumn{2}{|c|}{ ATCC 11778} & \multicolumn{2}{|c|}{ ATCC 27853} & \multicolumn{2}{|c|}{ ATCC 25922} & \multicolumn{2}{|c|}{ ATCC 13076} \\
\hline & 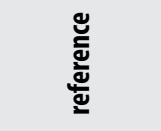 & 를 & 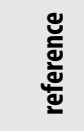 & 를 & 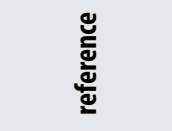 & 氕 & 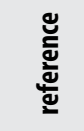 & 氖 & 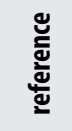 & 氖 & 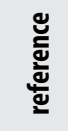 & 氖 \\
\hline N1 & - & $15.89 \pm 0.41$ & - & - & $14.46 \pm 1.16$ & $12.82 \pm 0.89$ & - & - & - & - & - & - \\
\hline N2 & - & $17.02 \pm 0.32$ & - & - & $14.60 \pm 0.81$ & - & - & - & - & - & - & - \\
\hline N3 & $11.23 \pm 1.10$ & $16.40 \pm 0.87$ & - & - & $13.99 \pm 0.51$ & $10.60 \pm 1.44$ & - & - & - & - & - & - \\
\hline N4 & - & $16.01 \pm 0.25$ & - & - & $13.83 \pm 1.42$ & $13.44 \pm 0.71$ & - & - & - & - & - & - \\
\hline N5 & - & - & - & - & - & - & - & - & - & - & - & - \\
\hline
\end{tabular}


antimicrobial activity against the tested microorganisms and had the lowest antioxidant activity.

Received 30 January 2018 Accepted 7 March 2018

\section{References}

1. T. O. Cheng, Int. J. Cardiol., 108, 301 (2006).

2. M. Bancirova, Food Res. Int., 43, 1379 (2010).

3. W. Chen, L. Shidong, W. Yuanshuang, et al., Springerplus, 5(576) (2016).

4. M. Czernicka, G. Zaguła, M. Bajcar, et al., Rocz. Panstw. Zakl. Hig., 3(6), 237 (2017).

5. J. L. Marnewick, F. Rautenbach, I. Venter, et al., J. Ethnopharmacol., 133, 46 (2011).

6. J. G. Napolitano, T. Gödecke, D. C. Lankin, et al., J. Pharm. Biomed. Anal., 93, 59 (2014).

7. E. Joubert, P. Winterton, T. J. Britz, et al., Food Res. Int., 37, 133 (2004).

8. V. R. Preedy, Tea in Health and Disease Prevention, 1st edn., Churchill Livingstone Elsevier, Amsterdam (2013).

9. O. R. Ajuwon, J. L. Marnewick, L. M. Davids, in: S. J. T. Gowder (ed.), Basic Principles and Clinical Significance of Oxidative Stress, Vol. 1, Ch. 7, InTechOpen (2015).

10. M. P. Almajano, R. Carbo, J. Angel Lopez Jimenez, et al., Food Chem., 108, 55 (2008).

11. J. Oh, H. Jo, A. R. Cho, et al., Food Control, 31, 403 (2013).

12. E. Joubert, P. Winterton, T. J. Britz, et al., J. Agric. Food Chem., 53, 10260 (2005).

13. A. Kumar, A. Kumar, P. Thakur, et al., Recent Res. Sci. Technol., 1(4), 19 (2012).

14. W. Brand-Williams, M. E. Cuvelier, C. Berset, Lebensm. Wiss. Technol., 28, 25 (1995).
15. B. Dereje, A. Minaleshewa, T. A. Mirtachew, Springerplus, 5(412) (2016).

16. T. Iannitti, V. Rottigni, B. Palmieri, J. Oral Pathol. Med., 9(416), 49 (2012).

17. S. C. Forester, J. D. Lambert, Mol. Nutr. Food Res., 6(55), 844 (2011).

18. S. P. J. Namal Senanayake, J. Funct. Foods, 5(4), 1529 (2013).

19. W. C. Reygaert, Front. Microbiol., 5(434) (2014).

20. M. Shohayeb, E. Halawani, Int. J. Adv. Res., 5(2), 562 (2017).

21. P. Muniandy, A. B. Shori, A. S. Baba, Food Packaging Shelf Life, 8, 1 (2016).

Kristina Ramanauskienė, Aidas Grigonis, Valdimaras Janulis, Raimondas Raudonis, Lina Babickaitė, Asta Marija Inkènienė

\section{ŽALIOSIOS IR RAUDONOSIOS ARBATŲ VANDENINIŲ IŠTRAUKŲ KOKYBĖS TYRIMAS}

Santrauka

Žalioji ir raudonoji arbatos sulaukia intensyvių mokslinių tyrimų dèl stiprių antioksidacinių, priešuždegiminių, antimikrobinių, priešnavikinių savybių. Straipsnyje analizuojama skirtingų fermentacijų žaliosios ir raudonosios arbatų cheminè sudètis bei biologinis aktyvumas. Vandeniniai ekstraktai buvo pagaminti buitinemis paruošimo sąlygomis ir vertinta ekstrahavimo laiko ịtaka veikliụjų junginių išsiskyrimui iš žaliavos. Antibakterinis aktyvumas ịvertintas difuzijos metodu in vitro. Tyrimų rezultatai parodè, kad žaliojoje arbatoje dominuoja katechinai ir kofeinas, raudonojoje - nustatytas rutinas ir galo rūgštis. Žaliosios arbatos ištraukos slopino $S$. aureus ir B. cereus bakterijų augimą. Remiantis antioksidacinio aktyvumo tyrimų rezultatais arbatas pagal antioksidacini poveiki galima surikiuoti tokia seka: žalioji $>$ baltoji $>$ Oolong $>$ raudonoji.

Raktažodžiai: arbata, kokybès vertinimas, katechinai, antimikrobinis aktyvumas 